\title{
Treatment of Torture under Albanian and International Legislation, Constitutional Problems
}

\author{
PhD Student Oljana Hoxhaj \\ The Justice Department, University "Ismail Qemali"Vlora \\ oljana.hoxhaj@gmail.com
}

\section{Doi:10.5901/ajis.2014.v3n4p253}

\section{Abstract}

The aim of the paper is the treatment of torture in the viewpoint of national and international law. The prohibition of torture was sanctioned by the design of the Universal Declaration of Human Rights, to continue further with other global and regional instruments in the field of human rights. It is important to note that simultaneously with these developments; the prohibition of torture is particularly reflected in the constitutional right. In Albania, the lawmaker has sanctioned the prohibition of torture in the Constitution and criminal law. International law in the field of human rights sanctions as a rule, only a basic minimum of freedoms and rights. The innovation of this paper is the treatment of torture in the context of an important constitutional issue consisting to the expansion of subjects, with a view to ensure greater protection for individuals aggrieved by such offense. The consequences caused to the victim are serious. Therefore, I think that, the subject who performs criminal offense should not condition the qualification of offense. Hence, the subject should be general, not only a public official.

Keywords: legislation, constitution, public official, integrity.

\section{Meaning of Torture}

In judicial practice, more questions arise over the definition of "torture" As the extent of the circle of subjects that may be involved in case of performing this criminal offense. Our Constitution in the chapter of personal rights and freedoms, guarantees the individual's non-subjection to torture, inhuman or degrading treatment. (ACRTT, 2004, p 7)

Based on the constitutional disposition that prohibits torture, the Criminal Code provides:"The intentionally performing of criminal offenses, through which to a person have been caused severe physical or mental suffering by a person that execs public functions or at his open or hidden instigation or consent, in order:

a. to get from him or another person information or a confession,

b. to punish him for an act committed or suspected to have been committed by him or another person;

c. to intimidate or put pressure on him or another person,

d. for any reason based on discrimination of any form,

b. any other inhuman or degrading treatment constitute a criminal offense and sentenced from four to ten years. "(Elezi, 2007, p 80)

According to the Supreme Court, the meaning of torture given in the above mentioned dispositions of the Criminal Code is different from the constitutional formulation and and that of the international legal instruments. This because considered as a criminal offense committed by the officials or with their promotion, mostly against persons deprived of freedom, or people who face the police.In view of the Supreme Court, the establishment of legal provisions in the Criminal Code is not in accordance with what is provided in international instruments,because the circle of relationships that are protected gets narrower sense than that given in international acts and in the dispositions of the Criminal Code. (ACRTT, 2004, p 9)

\section{The Torture According to the Treatment of the European Convention on Human Rights}

No one shall be subjected to torture or to inhuman or degrading treatment or punishment.

The rights protected by Article 3 of the Convention are directly related to the personal integrity and human dignity of the individual.Thus, the freedom from torture, inhuman treatment or punishment and degrading are rights of exceptional importance.Under Article 15 of the Convention, they are intolerable.The European Court of Human Rights has done differentiation between three substantive concepts in Article 3, in terms of the degree of severity of treatment or 
special punishment.Torture means cruel treatment that causes serious and cruel suffering. Inhuman treatment or punishment means an infliction of an intense physical and mental suffering.Degrading treatment means mistreatment intended to create on victims: feelings of fear, anxiety, inferiority, to humiliate him and possibly breaking their physical and moral endurance. (Gomien, 2005, p 22).

Torture is a higher degree of maltreatment that is prohibited by the European Convention on Human Rights. In a series of documents, General Assembly of the UN has defined torture as an act that causes severe pains and physical or mental sufferings as well as deliberately performed by a public official to obtain a confession or information from the victim. Degrading treatment means manner of treatment that heavy humbles the individual and forces him to act against his will and consciousness.

Important aspect is the treatment of prisoners and all international instruments provides that the establishment of sentenced persons in isolation constitutes a violation of international standards. In order to guarantee the freedom to not be subjected to torture is approved as additional element the International Convention on the Prevention and Elimination of Torture and Inhuman Treatment. (Cobani, 2002, p 54)

\section{Constitutional Problems}

The decision of the Supreme Court, although claims for unconstitutionality of the provisions of the Criminal Code dealing with torture is not justified in what part of Article 25 of the Constitution or its other provisions affected by the wording of Articles 86 and 87 of the Code Criminal.The same can be said for international acts, in which Republic of Albania has adhered to.In the constitutional context, disagreeing on torture, punishment or cruel, inhuman or degrading treatment is included as constitutional guarantees in the chapter of freedoms and personal rights. While Articles 86 and 87 of the Criminal Code do nothing other than, they ensure the implementation of this constitutional obligation through sanctions in case of consumption of the offense of torture.In other words, the articles 86 and 87 of the Criminal Code are a direct consequence of Article 25 of the Constitution.

Determination of the above provisions in one or another part of the Criminal Code has no constitutional relevance, but may constitute the subject of discussion in the background of legislative technique.Similarly, narrowing or widening of the subject can be criminally liable for the acts provided for in Articles 86 and 87 does not bring constitutional implications character, as long as predicted intentionally the commission of these acts.Even in the literature of Albanian criminal law, it is recognized that the subject of crime is a person who has reached a certain age for criminal responsibility and is accountable, general or special subject, civil or military. The expansion of responsible parties is in accordance with the spirit conveyed by the formulation of international treaties on positive obligations arising for States Parties, as well as in international jurisprudence in the field of human rights.

The Committee for Human Rights has related the right not to be subjected to torture and maltreatment under Article 7 of the Pact on Civil and Political Rights - with the obligation of the state to provide protection through legislative measures or other measures against torture or maltreatment by private individuals. The purpose of Article 7 of the Pact is to protect the dignity and physical and mental integrity of the individual.Therefore, it is duty of every State party to provide protection to everyone through legislation and other measures that may be considered necessary against the acts prohibited by article 7 , whether caused by people acting in an official capacity, such outside official capacity or in a private capacity.

The European Court of Human Rights well known for its practice of horizontal dimension, that has given substantial protection of the rights provided by the Convention says that: the obligation of Member States from Article 1 of the Convention to secure to everyone that is under its jurisdiction the rights and freedoms set forth in the Convention, combined together with its Article 3, requires from member States to take measures designed to ensure that individuals within their jurisdiction are not subjected to torture or inhuman or degrading maltreatment, including abuses committed by private individuals.

While the International Court of Human Rights says that the obligation of member states to the American Convention, to ensure the exercise of rights under the Convention, includes the obligation of Member States to organize their governing apparatus, and in general, the structures through which exercised public power in order to be able that, legally to provide free and full joy of human rights because, and only an illegal act which violates human rights and which is not carried out by the state can lead to international responsibility of the state, not due to the fault of the act itself, but because of lack of proper diligence to prevent the violation or to respond to what is required by the Convention.

At the same constitutional spirit relying on the doctrine of international law, the Albanian Constitutional Court concluded that: as long as the prohibition of torture and maltreatment is defined as a human right and as long as human 
rights are considered as indivisible and inalienable and inviolable, everyone has the right not to be subjected to torture or maltreatment, whether it is in the hands of a public official or an individual.

In its decision, the Constitutional Court goes further by recognizing the State's obligation to protect its citizens from the commission of torture or maltreatment by public officials, but also in the obligation to take effective measures to protect people against acts of torture or maltreatment carried out by individuals.In short, the Constitutional Court by the above reasoning gave to prohibition of torture horizontal dimension of protection, in daily practice.

The Constitutional Court decision is also important because of the recognition of the role of international law.According to the Constitutional Court, the international law in the field of human rights sanctions as a rule only a basic minimum of freedoms and rights, while the states party to international conventions can rise above these minimums and implement national laws that contain or may contain provisions to a broader character.In fact, this approach consolidates constitutional jurisprudence. (ACRTT, 2004, p 10)

My opinion is that the treatment and reasoning that has made the Constitutional Court is a professional treatment, which significantly prevails the purpose to ensure greater protection for individuals aggrieved by such offense, where the danger is quite high and the integrity of the person, both physical and psychological significantly affected.The expansion of subjects, in my opinion, is necessary because the consequences suffered by the victim are serious and the subject performing the criminal offense, so the subject should be general, not just public official, he should not condition the qualification of the offense.

\section{Treatment of Inhuman or Degrading Punishment}

Although torture occurs only in the context of the sentence, the Court has found a violation of the prohibition of inhuman or degrading treatment or punishment humiliating both within and outside the context of the sentence.Violations of Article 3 considered the case when individuals submitted timely the documentation on alleged damages during the time they have been under police surveillance and when the government did not offer any credible alternative explanation about the cause of these injuries. The Court stressed that the fight against terrorism and organized crime cannot constitute a reason to justify mistreatment of prisoners.Any recourse to the use of force that was not strictly necessary to happen due to the behaviour of offender is inconsistent with the article 3.

A state has task to ensure that the use of force against an individual during the arrest also does not preclude the prohibition of maltreatment.The state's duty is to ensure that a convict is not subject to abuse and take positive action to protect him from abuse by other prisoners. The Court has emphasized that when a person dies in custody or under supervision, is the state's duty to provide a clear explanation regarding the cause of death and in particular, the data storage much more detailed and fresh, related to each damage caused to the individual.

In most prisons in countries that still have the death penalty regime, individuals sentenced to capital punishment often are placed in separate cells from ordinary prisons and are subject to a special regime of violence, as well as other adverse conditions. These factors attached and the long time, which a prisoner must wait on death row in the United States, have led the Court to emphasize that we are ahead of the violation of Article 3.

An individual in prison is totally dependent on government authorities to meet its basic needs.Being of prisoners so vulnerable leads to the obligation of the authorities to take into account the requirements and needs of each prisoner as during detention, also during all the time that this person will remain under the custody and control of the government. Occasionally the Court has reviewed the complaints about the institutionalization of comprehensive policies and practices of the state, which have a negative effect on the population and which lead to abuses under Article 3 of the Convention. The extension of discriminatory practices that violate a certain group of the population where is infringed the dignity and moral integrity, is considered a degrading treatment contrary to the article 3.

The Court has had the same perspective in assessing the procedural aspects of claims of violations of Article 3.If the Court is unable to determine if the alleged maltreatment occurred in fact, it will however make an independent assessment of the ability of government to respond to the pretentions.In cases where individuals claim to have been abused during their stay in places of detention, the Court can expressed that it is impossible to establish the facts, but it may find a violation of Article 3 if the prosecutors have been investigating over the raised claims, are not able to meet the required standards of efficiency. (Council of Europe, 1998, p. 24)

In relation to the medical treatment given to a person confined in a psychiatric hospital, the Court considers that the position of inferiority and lack of power, which is typical for such patients require the increase vigilance in reviewing whether the Convention is implemented.Whereas belongs to medical authorities to decide on the basis of recognized rules of medical science, therapeutic methods used, if necessary, even by force to maintain physical and mental health of 
patients who are completely disabled to decide and who they are therefore responsible, such patients nevertheless remain under the protection of Article 3, whose requirements do not allow any derogation.Established principles of medicine are accepted as crucial principally in such cases, as a general rule, a measure that is therapeutic necessity cannot be regarded as inhuman or degrading. However, the Court must establish the existence of the conviction that medical necessity is satisfactorily shown. (Report)

\section{Comparative Overview of International Legislation and Albanian Legislation on Torture}

Torture and inhuman and degrading each, are prohibited under international law of human rights, and international criminal law. Proof of above assertion are provisions of the Pact on Civil and Political Rights, the Convention against Torture of the UN, the Optional Protocol of UN Convention against Torture, the European Convention of Human Rights, the Convention against Torture of the Council of Europe, Rome Statute of the International Criminal Court, Statute of the International Criminal Tribunal for the former Yugoslavia, the Statute of the International Criminal Tribunal for Rwanda, the Inter-American Convention on Human Rights, the Universal Declaration of Human Rights and the African Charter on the Rights Human and Peoples.Can be said without hesitation that the prohibition of torture and humiliating and degrading treatment is reflected even in the majority of treaties contained within the various disciplines of international law.

Besides conventional aspect, the prohibition of torture has become an integral part of international law.International customary law is a source of international law and as confirmed by the International Court of Justice, it constitutes by objective side, otherwise known as international rules derived from the practice of states for a long time, which rely on subjective side, so in a legal opinion that is considered as law. The practice of states in itself is not enough, it must be accompanied with the conviction of states that a certain form of behaviour required by the international law.Committee for Human Rights has emphasized that the obligation to not be subjected to torture or ill-treatment is a rule of customary international law, and the prohibition of torture constitutes an unquestioned norm. The European Court of Human Rights shares the same attitude and considers the prohibition of torture as an unquestioned norm in the international law.

Meanwhile, the Constitutional Court considers the obligation to not be subjected to torture or ill-treatment as a rule of customary international law and that the prohibition of torture constitutes an unquestioned norm. Although the Constitutional Court indirectly acknowledged the importance of international custom, she did an assessment of customary international judicial power in the constitutional context. The prohibition of torture, as an irrefutable rate may be distinguished also clearly on the background of not hearing. Article 15/2 of the European Convention of Human Rights lists the prohibition of torture, the inhuman and degrading treatment together with Article 2, "the right to life", Article 4/1 "prohibition of slavery and forced labour", Article 7, "It has not punishment without law", as well as among the nonderogable rights, even in case that a state is faced to an situation or a state of emergency. However, Article 2 allows the "taking of life" when it comes as a result of the use of force when it is absolutely necessary. The same thing provides also Article 2 of Protocol 6 of the Convention. Meanwhile, the exceptional cases of Article 7 of the Convention can be applied in situations of international armed conflict. Thus, the prohibition of torture and inhuman or degrading treatment, the prohibition of slavery and forced labour rights are non-derogable absolutely in whatever circumstance.

In cases where applicants claim they were maltreated in the most extreme possible, the European Court of Human Rights stated that Article 3 constitutes one of the fundamental values of democratic society. Unlike many provisions of the Convention and the Protocol no. 1 and 4, Article 3 has no provision for exemption or deviation from it, allowed under Article 15 and in cases of public emergency threatening the life of a nation. Norms or obligations with erga omnes nature are liabilities arising from the norms of customary international law, which are addressed to all international community as a whole and enjoy a superior status in international law in relation to common rates. These rates are obligatory to be implemented in case of non-accession of Albania into one or some international instruments that prohibit the use of torture.

Therefore, the obligations with erga omnes nature, derived from the moment that the rate has acquired the status of jus cogens. Consequently, the state should take effective measures to prevent torture, punish torture and punish actions that qualify as acts of torture. So ordinary courts, and moreover the Supreme Court, which is competent instance to unify the legal practice, must analyse the elements of the criminal offense in accordance with the Constitution and the definition offered by international law obligatory for the Republic of Albania. Albanian Constitution in its Article 5 states: "The Republic of Albania applies international law binding on him."

Binding international law for Albania is not simply the totality of the obligations arising from international instruments, conventions, pacts, agreements, treaties that adheres to Albania, but also the norms of customary 
international law and general principles of customary international law, which constitute a source of international law under Article 38 of the Statute of the International Court of Justice.The Constitutional Court must make an extended interpretation, final and functional of article 5 of the Constitution, thereby by avoiding the casuistic attitude regarding his legal power.Such rate, not only cannot be ignored, but they should be considered as part of the domestic law of states. Like this approach is adopted by many countries such as Holland, Germany, Spain, Belgium etc... (ACRTT, 2004, p 11)

\section{Conclusions}

Torture, as one of the offenses that takes heavy toll on the integrity of the person is displayed in different forms, in different periods in Albania. Period of communism spread a wide number of means by which people realized torture. Methods to suppress the public included pressures through the introduction of fear, internment for moral and economic problems. But unquestionably the most extreme form was the violence in prisons involving beating, punching of meat with hot tools, electric shock, starvation and many others. Psychological torture, realized through depriming, humiliation and intimidation, and that families of the victims would be killed.

The collapse of the communist regime in Albania was accompanied by the establishment of a regime based: on market economy, respect for freedoms, human rights and on the free and democratic elections.During this period, there were fundamental changes in domestic legislation to ensure the democratization of the Country.It was released political prisoners, were took measures for their social rehabilitation. Restrictions on freedom of expression and political assembly were removed. Currently, the Albanian state is considered a democracy, since adheres to a number of conventions and international acts guaranteeing democracy at the national level. However, Albania remains a poor country and the institutions are still fragile and unconsolidated. (AHRG, 2005, p 24)

I think that accession to Conventions has marked a positive step in the democratization of individual rights, but there are still many problems, which are reflected in the reports of various international organizations, but also in the Ombudsman's report, which recently has been present in the disturbing issues, particularly regarding the conditions of the prisoners.

\section{Refernces}

The Constitution of the Republic of Albania

European Convention of Human Rights

Omari. L, Anastasi. A, 2008,"E Drejta Kushtetuese", ABC, Tirana

Elezi I, 2007,"E drejta penale”, Erik, Tirana

Criminal Code of Albania

Gomien D., 2005, "Short Guide to the European Convention of Human Rights", Gent Graphic, Tirana

Mole N. Harby C., 2005, "The right to a fair trial", Gent Graphic, Tirana

Juridical Magazine," Jeta Juridike", 2005, Tirana

The Pact on Civil and Political Rights

Alternative Report, 2005, "State Violence in Albania", Tirana

Albanian Center for Rehabilitation of Trauma and Torture, 2004 "Summary of international acts of torture", Tirana

Albanian Center for Rehabilitation of Trauma and Torture, Alternative Report, 2007, "On the situation of torture in Albania 2006-2007", Natyra, Tirana 
